\title{
Marketing Efficiency of Chicken's Egg in Binjai City, North Sumatra
}

\author{
K Pargita, A H Daulay, N Ginting, Y L Henuk, E Mirwandhono \\ Animal Production Program Study, Faculty of Agriculture, University of North \\ Sumatera, Medan 20155, Indonesia \\ E-mail: kikipargita220@gmail.com
}

\begin{abstract}
The egg marketing by producers usually uses various marketing agencies so that chicken eggs will reach consumers. This process requires marketing costs to be used to perform marketing functions. Therefore, research is conducted to investigate the marketing channels, marketing institutions, marketing functions and investigate the marketing efficiency of chicken's egg found in Binjai City. This research was conducted from July to August 2018. The method used in data collection is the withdrawal of a sample of retailers using the purposive sampling method, while the sample of farmers and other marketing institutions with snowball sampling. Data collection was done by interview technique using a questionnaire.

Data analysis includes marketing costs, marketing margins, farme'r share and cost benefit ratio of each marketing channel. The results of this study indicate that there are two marketing channels. The smallest marketing margin is obtained by the second marketing channel, therefore the second marketing channel has the largest ratio of profit to cost. The biggest farmer's share is obtained in the second marketing channel, this channel only uses retailers as an intermediary channel. So it can be concluded that the second channel is the most efficient channel because it has the smallest cost and the profit is spread evenly across all the marketing institutions that play a role.
\end{abstract}

\section{Introduction}

Chicken's egg are one of the livestock products that have a very important and strategic role in fulfilling community nutrition. Besides the relatively cheap price, chicken eggs also have high nutritional content, especially protein and high digestibility by the body. Another factor that causes an increase in demand for eggs is increasing population, improving the economy of the community and awareness of the importance of nutrition for the health of the human body.

Binjai is one of the centers of egg-producing laying hens in North Sumatra. Chicken is one of the most popular types of poultry in the community. Laying chicken breeding populations in Binjai City are spread in South Binjai District, North Binjai District and West Binjai District. The production of chicken eggs in Binjai City according to the Binjai City Food and Agriculture Resilience Office in 2012 was 9573.25 tons, in 2013 as many as 8838.4 tons, in 2014 as many as 799.27 tons, in 2015 as many as 8527 tons and in 2016 as many as 9017 tons [1].

\section{Materials and Methods}

2.1 Time and place of research

This research was conducted in the traditional market of Binjai City, North Sumatra province, namely the tavip market in Binjai Kota District and the morning market of pepper gardens in Binjai Utara District, taking into account that the two markets were the largest traditional markets in Binjai, where there were broiler traders. This research was conducted from July to August 2018. 


\subsection{Sampling technique}

Determination of the sample in this study was carried out by purposive sampling method, which is bro chicken egg traders in the tavip market and the morning market of kebun lada in the city of Binjai. Determination of respondents of marketing institutions carried out by snowball sampling method, this method was obtained from information obtained after going through interviews with previous respondents regarding the marketing channels of chicken eggs in the traditional market in Binjai City. This method is carried out with the aim of studying the flow of products and the involvement of marketing institutions in carrying out the marketing function, according to Singarimbun and Effendi [2]..

\subsection{Method of collecting}

The data collected in this study consisted of primary data and secondary data. Primary data obtained from questionnaires, observations and interviews in the field. While secondary data is obtained from various related agencies, such as the Central Bureau of Statistics and from other agencies related to research and from literature, books or journals.

\subsection{Processing Method and Analysis data}

2.4.1 Marketing channels and institutions

Channels and characteristics of marketing institutions involved in the marketing of laying hens products can be known through direct interviews with producers of chicken eggs and distribution channel institutions involved in them. Analysis of channel data and marketing institutions in a descriptive analysis.

\subsubsection{Analysis of marketing functions}

Analysis of the marketing function is used to observe the marketing functions carried out by each marketing institution in the marketing channels of race chicken eggs that are formed including exchange functions (buying and selling), physical functions (storage, transportation, processing), and facility functions (financing, holdings risk, standardization and grading, and market information).

\subsubsection{Marketing margin analysis.}

Marketing margin is the difference in price received by the producer farmer with the price paid by the end consumer, so that the margin can be systematically written as follows:

Information:

$$
M P=P r-P f
$$

MP = Marketing margin (Rupiah/item)

$\operatorname{Pr} \quad=$ Price at the consumer level (Rupiah/item)

Pf $\quad=$ Price at producer level (Rupiah/item)

\subsubsection{Farme'r share analysis}

Marketing efficiency analysis can be seen from the share of prices received by producers according to Fanani [3].

$$
\mathrm{SP} f=\frac{\mathrm{Pf}}{\mathrm{Pr}} \quad \mathrm{x} 100 \%
$$

Information:

SPf = Farmer's share / share received by the farmer (\%)

Pf = Prices received by farmers (Rupiah/item)

$\operatorname{Pr} \quad=$ Price paid by consumers (Rupiah/item)

\subsubsection{Profit and Cost Ratio (R / C)}

The ratio of profit and marketing costs is the amount of profit received for marketing costs incurred according to Limbong and Sitorus [4]. 


$$
\text { Profit / Cost ratio }(\%)=\frac{\text { profit }(\pi)}{\text { marketing cost }\left(\mathrm{C}_{\mathrm{i}}\right)} \quad \mathrm{x} 100 \%
$$

\subsubsection{Marketing efficiency}

Marketing efficiency $=$ Total marketing cost $x 100 \%$

Total product price

\section{Results and Discussion}

\subsection{Marketing institutions}

This research related to chicken eggs in Binjai City was used to donate ras chicken eggs from farmers to end consumers. The city of Binjai is one of the regions producing chicken eggs. Based on the results of the research that has been conducted, there are three companies, namely farmers, wholesalers and retailers.

\subsection{Marketing channel}

In the activity of exporting chicken eggs in the traditional market in Binjai City there are two marketing channels that connect producers and consumers to deliver their produce. This can be seen in the following table:

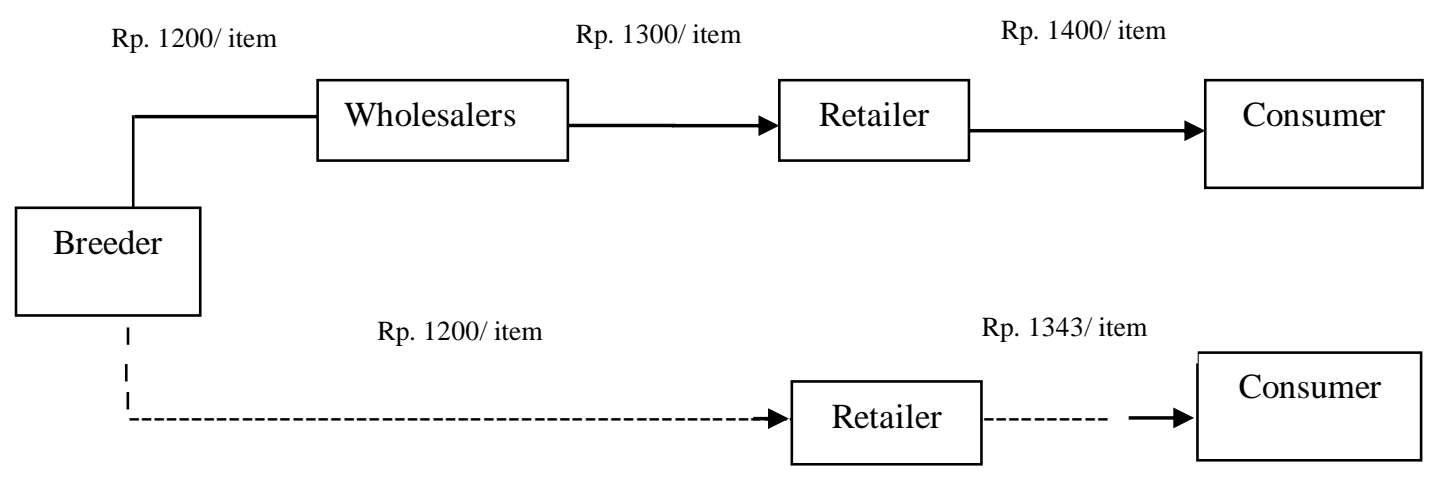

Figure 1. Marketing Channel

Keterangan :

Marketing Channel I

Marketing Channel II

\section{Marketing Channel I}

The type of marketing based on Figure 1 is two-level marketing because this channel uses two intermediary institutions namely wholesalers and retailers. These farmers market large quantities of chicken eggs so that they are marketed through wholesalers and wholesalers to market chicken eggs to retailers. Retailers take eggs from large traders because the market distance is far from farmers.

\section{Marketing Channel II}

The type of marketing based on Figure 1 is marketing one level because this channel uses only one intermediary institution, namely broiler retailers. Farmers who are producers in this channel are from the Binjai City area. Race chicken breeders in this channel produce eggs in sufficient quantities. Egg channel on this one channel comes from farmers to retailers who are not far from the location of the farm. 
3.3 Marketing function

Marketing functions carried out by marketing institutions in each of the marketing channels for chicken eggs in Binjai City can be seen in the following table.

Marketing functions when viewed from the table above, in the exchange function, the sales function is carried out by every marketing institution involved, including farmers. While the purchasing function

\begin{tabular}{|c|c|c|c|c|c|c|c|c|c|}
\hline \multirow{3}{*}{$\begin{array}{l}\text { Marketing } \\
\text { channel and } \\
\text { intitutions }\end{array}$} & \multicolumn{9}{|c|}{ Marketing function } \\
\hline & \multicolumn{2}{|c|}{ Exchange } & \multicolumn{3}{|c|}{ Physical } & \multicolumn{4}{|c|}{ Facilities } \\
\hline & Sell & Buy & Transport & Pack & Save & Sorting & $\begin{array}{c}\text { Risk } \\
\text { management }\end{array}$ & Cost & $\begin{array}{c}\text { Market } \\
\text { information }\end{array}$ \\
\hline \multicolumn{10}{|l|}{ Channel I } \\
\hline Breeder & $\sqrt{ }$ & - & - & $\sqrt{ }$ & $\sqrt{ }$ & $\sqrt{ }$ & $\sqrt{ }$ & $\sqrt{ }$ & $\sqrt{ }$ \\
\hline Wholesalers & $\sqrt{ }$ & $\sqrt{ }$ & $\sqrt{ }$ & - & $\sqrt{ }$ & - & $\sqrt{ }$ & $\sqrt{ }$ & $\sqrt{ }$ \\
\hline Retailer & $\sqrt{ }$ & $\sqrt{ }$ & - & $\sqrt{ }$ & $\sqrt{ }$ & $\sqrt{ }$ & $\sqrt{ }$ & $\sqrt{ }$ & $\sqrt{ }$ \\
\hline \multicolumn{10}{|l|}{ Channel II } \\
\hline Breeder & $\sqrt{ }$ & - & - & $\sqrt{ }$ & - & $\sqrt{ }$ & $\sqrt{ }$ & $\sqrt{ }$ & $\sqrt{ }$ \\
\hline Retailer & $\sqrt{ }$ & $\sqrt{ }$ & $\sqrt{ }$ & $\sqrt{ }$ & $\sqrt{ }$ & $\sqrt{ }$ & $\sqrt{ }$ & $\sqrt{ }$ & $\sqrt{ }$ \\
\hline
\end{tabular}

is not carried out by each farmer in each marketing channel because the breeder is a producer that produces chicken eggs. The physical function in the form of saving is not carried out by all farmers in each marketing channel because every time they do the egg quotation activities, they are directly sold to the next market destination. The function of the facility in the form of a risk management function, cost and function of market information is carried out by all marketing institutions involved. Other functions such as transport, packing and sorting functions there are some marketing agencies that do but there are those who do not perform the function.

3.4 Marketing margin

The marketing margin of a commodity consists of marketing costs incurred by each marketing agency and the benefits received by broiler egg farmers and marketing institutions.

\begin{tabular}{|c|c|c|}
\hline \multirow{3}{*}{ Uraian } & \multicolumn{2}{|c|}{ Marketing channel } \\
\hline & 1 & 2 \\
\hline & Value (Rupiah/item) & Value (Rupiah/item) \\
\hline \multicolumn{3}{|l|}{ Breeder } \\
\hline Selling price & 1200 & 1200 \\
\hline Marketing costs & 15,71 & 18,44 \\
\hline \multicolumn{3}{|l|}{ Wholesalers } \\
\hline Purchase price & 1200 & \\
\hline Marketing costs & 4,19 & \\
\hline Profit & 95,81 & \\
\hline Selling price & 1300 & \\
\hline Margin & 100 & \\
\hline \multicolumn{3}{|l|}{ Retailer } \\
\hline Purchase price & 1300 & 1200 \\
\hline Marketing costs & 28,36 & 22,63 \\
\hline Profit & 71,64 & 120,37 \\
\hline Selling price & 1400 & 1343 \\
\hline
\end{tabular}




\begin{tabular}{lrr}
\hline Total Marketing Costs & 48,26 & 41,07 \\
\hline Total Profit & 167,45 & 120,37 \\
\hline Total Marketing Margin & 200 & 143 \\
\hline R/C Ratio & 3,864528041 & 2,930849769 \\
\hline
\end{tabular}

Based on the table above, the two channels for marketing chicken eggs in Binjai City, the biggest marketing costs are borne by the marketing channel I of Rp. 48.26 per item. This is because the marketing chain through two marketing institutions and the number of people being traded is very much. While the costs borne by marketing channels II are Rp. 41.07 per item which is the shortest marketing chain. The biggest marketing advantage is in the marketing channel I of Rp. 167.45 per item because it is the longest marketing chain. The smallest profit is in the marketing channel II of Rp. 120.37 per item. The biggest marketing margin is found in the marketing channel I, which is Rp. 200 per item because marketing channel I is the longest chain of marketing channels II. The smallest marketing margin is in the marketing channel I, which is Rp. 143 per item where on this path the farmer sells chicken eggs directly to retailers. The average consumer who buys chicken eggs is to be consumed directly. In this path there is a very close relationship and mutual trust so that farmers always maintain the quality of their eggs sold. In marketing channels I and II, the marketing margin is determined by the distribution distance and the short length of the marketing chain.

3.5 Farme'r share

Farmer 's share is a comparison between prices received by farmer's and prices paid by consumers, and is generally expressed as a percentage. The amount received by the breeders can be seen in the table below.

\begin{tabular}{crrr}
\hline $\begin{array}{c}\text { Marketing } \\
\text { channel }\end{array}$ & $\begin{array}{c}\text { Prices at the Farmer Level } \\
\text { (Rupiah/item) }\end{array}$ & $\begin{array}{c}\text { Price at the Consumer } \\
\text { Level (Rupiah/item) }\end{array}$ & Farmer's Share (\%) \\
\hline I & 1200 & 1400 & 85,71428571 \\
II & 1200 & 1343 & 89,35219657 \\
\hline
\end{tabular}

The table above shows the largest share of price (farmer's share) in the marketing channel II, which is $89.35 \%$, meaning that the farmer receives a price of $89.35 \%$ of the price paid by the consumer. While the marketing channel I obtained the lowest farmer share value that was equal to $85.71 \%$.

3.6 Profit and cost ratio

The profit per cost ratio analysis can be used to find out whether the marketing activities carried out provide benefits to the marketing actors.

\begin{tabular}{lccc} 
Marketing institutions & $\begin{array}{c}\text { Profit } \\
\text { (Rupiah/item) }\end{array}$ & $\begin{array}{c}\text { Cost } \\
\text { (Rupiah/item) }\end{array}$ & $\pi / \mathrm{C}$ \\
\hline
\end{tabular}

\begin{tabular}{llll}
\hline $\begin{array}{l}\text { Channel I } \\
\text { Breeder }\end{array}$ & 1200 & & \\
Wholesalers & 95,81 & 4,19 & 22,86634845 \\
Retailers & 71,64 & 28,36 & 2,526093089 \\
\hline Total & 167,45 & 32,55 & 5,144393241 \\
\hline Channel II & & \\
Breeder & 1200 & & \\
Retailers & 120,37 & 22,63 & 5,319045515 \\
\hline Total & 120,37 & 22,63 & 5,319045515 \\
\hline
\end{tabular}


In the table above, the marketing channel I has a total profit of Rp. 167.45 per item. The biggest profit is obtained by large traders, which is Rp. 95.81 per item, while the lowest profit is obtained by retailers, namely Rp. 71.64 per item. The total marketing costs incurred per egg is Rp. 32.55 . The lowest cost is borne by wholesalers, namely Rp. 4.19 per item, the highest marketing cost borne by retailers is Rp. 28.36 per item. Then the profit to cost ratio is 5.14. In the marketing channel II the profits obtained are Rp. 120.37 per item while the total marketing costs incurred by retailers are Rp. 22.63 per item. Then the profit to cost ratio is 5.32 .

\subsection{Marketing efficiency of chicken eggs}

The ultimate goal to be achieved in the marketing process is the efficiency of the marketing system that can provide satisfaction to all the behaviors involved in marketing. The value of marketing efficiency in the marketing channel for chicken eggs in the city of Binjai can be seen in the table below.

\begin{tabular}{llll}
\hline Marketing institutions & $\begin{array}{c}\text { Cost } \\
\text { (Rupiah/item) }\end{array}$ & $\begin{array}{l}\text { Product Value } \\
\text { (Rupiah/item) }\end{array}$ & $\begin{array}{l}\text { Efficiency Value } \\
\text { (Rupiah/item) }\end{array}$ \\
\hline $\begin{array}{l}\text { Channel II } \\
\text { Breeder }\end{array}$ & 18,44 & 1200 & 0,015366667 \\
Retailers & 22,63 & 1343 & 0,016850335 \\
Channel I & & & \\
Breeder & 10,78 & 1200 & 0,008983333 \\
Wholesalers & 4,19 & 1300 & 0,003223077 \\
Retailers & 28,36 & 1400 & 0,020257143 \\
\hline
\end{tabular}

Based on the formula of Downey and Erickson (1992) [5], the marketing system can be said to be efficient if the value of marketing efficiency is $<1$, by looking at the results of analysis in the table above, that the efficiency of all marketing institutions involved in marketing chicken eggs in Binjai City is $<1$ which means efficient. So from the two marketing channels, the most efficient marketing institution compared to other institutions is retailers. This is indicated by the small marketing costs, while the value of the products being marketed is the largest.

\section{Conclusion}

Marketing of chicken eggs formed in Binjai City consists of 2 marketing channels. The marketing institutions involved are breeders as producers of broiler eggs, wholesalers and retailers. Based on the analysis of marketing margins, farmer's share, and profit to cost ratio, the following conclusions are obtained: the smallest marketing margin is obtained by channel II, which is Rp. 143, - per item. The biggest cost benefit ratio is marketing channel II, in terms of farmer shares, channel II occupies the highest value of $89.35 \%$, and from the marketing efficiency, each marketing channel is efficient with a value of $<1$.

\section{Reference:}

[1] BPS 2016. Binjai dalam Angka. Badan Pusat Statistik Kota Binjai, Binjai.

[2] Singarimbun, M. dan Effendi, S. 1989. Metode Penelitian Survei. LP3ES. Jakarta.

[3] Fanani, Z. 2002. Efisiensi Pemasaran Ayam Pedaging Model Kemitraan di Kabupaten Malang. J. Ilmiah Ilmu Peternakan dan Perikanan. 18:1181 1190.

[4] Limbong, W. H., Sitorus, P. 1987. Pengantar Tataniaga Pertanian. Jurusan Ilmu-Ilmu Sosial Ekonomi Pertanian. Fakultas Pertanian. Institut Pertanian Bogor. Bogor.

[5] Downey, D. dan Erikson, S. 1992. Manajemen Agribisnis. Penerbit Erlangga. Jakarta. 